Research Article

Open Access

Inese Jurgena, Dagnija Cēdere

\title{
Students' Ideas on Innovations in Higher Education
}

DOI 10.1515/sigtem-2016-0014

\begin{abstract}
The academic staff plays a key role in the implementation of innovations, striving to introduce changes in the process of education and involving students in this process. The aim of this article is to analyse the ideas of students and pre-service teachers, on the role of innovations in the work of the academic staff at the institutions of higher education. The research is based on the analysis of scientific literature, regulatory documents, studies and surveys. The analytical data processing software SPSS was used for the analysis of the data. Having analysed the data of the survey involving the first-year students and preservice teachers, enrolled both in the full-time and part-time studies at RTTEMA, the authors conclude that readiness for innovative activity and active involvement in the creation, acquisition and application of innovations is an essential factor for amending the traditional activity of the academic staff. The authors gained convincing evidence of the idea that in pedagogy the term innovation refers to the process of renewal, educational reforms, the selection of the most appropriate material (idea, activity, form, method, means, concept, or programme) and their practical implementation, i.e. the creation, acquisition and application of innovations in the pedagogical practice.
\end{abstract}

Keywords: higher education, ideas, innovation, pre-service teacher.

\section{Introduction}

In the 21st century, each individual and the society as a whole has to learn to live in a constantly changing environment, to co-exist with changes and to change themselves. Along with the shift in the education paradigm, significant transformations are taking place in education as the notion of the knowledge society cannot be separated from the notion of the learning society. "The basis of extensive and deep high-quality knowledge is a precondition which, together with the human capital, is necessary so that the eco-system of innovations could create new knowledge” (Zinātnes, tehnologijas..., 2013, 43). Knowledge is becoming the main driving force for development in all areas of human activity.

Within the model of the learning society, innovations in education are changing human thinking, the understanding of values and erasing the boundaries between the formal and informal education. The notion of knowledge society is closely linked with the development of information and communication technologies - the wide use of digital technologies in education poses new challenges (Woods, 2002; Kapenieks, Salite, 2012). The use of technologies in the process of education is the sign of our epoch. Besides, technologies lead to changes in human thinking and perception (Prensky, 2001).

Nowadays, the issues concerning the ability of the institutions of higher education to be innovative are discussed more than ever before, both in Latvia, Europe and the world in general. The contemporary institutions of higher education have to devise ways to adapt to the reality of knowledge creation, which is

*Corresponding author: Inese Jurgena, Riga Teacher Training and Educational Management Academy, Latvia, E-mail: inese. jurgena@rpiva.Iv

Dagnija Cēdere: Riga Teacher Training and Educational Management Academy, Latvia, E-mail: dagnija.cedere@rpiva.Iv

(๕)BY-NC-ND (c) 2016 Inese Jurgena, Dagnija Cēdere, published by De Gruyter Open.

This work is licensed under the Creative Commons Attribution-NonCommercial-NoDerivs 3.0 License. 
essentially different from the traditional way of knowledge creation and its implementation at the corresponding institutional level.

However, there are only a few studies concerning transformations in the Latvian institutions of higher education (Tisenkops, Bela, 2011; Gedžūne, 2014; Lukjanska, 2014), and they mainly deal with the analysis of structural changes in these institutions. The issue concerning the internal innovation processes underlying the changes and the realisation of the diverse roles of educational institutions, as well as students' views on the implementation of innovations in educational institutions have been studied much less frequently.

The constantly developing system of teacher education is one of the possibilities for change in Latvia. The essence of sustainable higher education is to ensure individual's ability to adapt to the conditions of the changing environment, to prepare people for professional activity in the information society and to create opportunities for everyone to develop himself/herself creatively and to change one's standard experience of life activity (Grabovska, 2006).

The refocusing of education on sustainability is particularly important in teacher education since teachers are entrusted with the responsibility of taking care of young people - the new link in the chain of the evolution of human consciousness; it depends on the teachers whether this evolution will proceed in the direction of inclusion (UNESCO, 2005; Fried, 2006; Grabovska, Grabovskis, 2009). In scientific literature, these goals of teacher education are linked with the attempts to help would-be teachers attain sustainability, i.e. inclusive wisdom (Salīte, Gedžūne, 2009). The refocusing of students (pre-service teachers) on the aim of sustainability also includes the issues of innovations in the process of studies.

Contradictions can be seen in the system of higher education in Latvia, including professional teacher training. Undoubtedly, the academic staff working in the institutions of higher education ensure the passing of knowledge, skills and values on to the new generation as well as the stability of the system of education; nevertheless, their pedagogical activity is often focused on the delivery of reproductive knowledge and skills by following old stereotypes, patterns and algorithms. It is not often that the innovative trend - active involvement in the creation and acquisition of innovations, as well as the use of innovations in the process of education - manifests itself in the work of the academic staff at the institutions of higher education (Baltušìte, 2012; Kunda, 2014; Kapenieks, 2013; Brigmane, 2014).

\section{Aim of the Study}

The aim of this study is to analyse the views of students (future educators) about the manifestations of innovations and their role in the work of the academic staff at the institutions of higher education.

\section{Materials and Methods}

Along with a paradigm shift in education in the new social-economic conditions, there has appeared the need to bring to the foreground the issue concerning innovations in education. Within the framework of the new paradigm, many new or modern ideas are introduced in education: the idea of humanisation and humanitarisation; the democratisation of the process of education, the idea of the optimisation and intensification of the process of learning, the idea of continuous education, the idea of cooperation, etc. The common strategy of these ideas is the activation of personality in the process of education and the acceptance of creativity - the key feature of innovative activity (Юсуфбекова, 1990; Поляков, 1993; Кларин, 1995; Пригожин, 1989).

With regard to the understanding of pedagogical innovations, attention was initially focused on the implementation of the latest scientific discoveries in practice, the introduction of the best practices. However, it was concluded that in order to use "innovations" in teacher's actual work, it is not enough to familiarise oneself with the models of the best practice and analyse them. The implementation of innovations in the process of education is specific. Clearly, 'the specific nature of the pedagogical process lies in the fact that it is affected by the personal qualities of both the teacher and learners and supplemented by the elements of improvisation, which considerably change any previously prepared, idealised project of the 
pedagogical activity' (Беспалько, 1995, 59). The introduction of innovations cannot be copied; it is connected with a teacher's personal experience (Кларин, 1995, 164); innovations refer to qualitative changes in the personality, and they change individual's thinking (Пригожин, 1989, 56).

The position of the authors of the article is underpinned by the idea that in pedagogy the term 'innovation' refers to the process of renewal, educational reforms, the selection of the most appropriate material (idea, activity, form, method, means, concept or programme) and their practical implementation, i.e. the creation, acquisition and application of innovations in the pedagogical practice (Бережная, 2010; Беспалько, 1989; Бондаревская, 2008).

Teachers who strive to introduce changes and involve their students in this process play a key role in the introduction of innovations. Based on the reflection, activity and experience of the participants in the process of education as well as the formation of the new system of reference, it is possible to promote directly the introduction of innovations in practice (Gedžūne, 2014; Grabovska, Grabovskis, 2009).

At present, there are limited possibilities for the application of progressive pedagogical ideas offered in scientific literature in the actual study process at the institutions of higher education. It is important to clarify what are students' ideas about the manifestations of innovations and their role in the work of the academic staff.

The methods used in the present research are the theoretical method (the analysis of scientific literature), regulatory documents and studies and the empirical method (student surveys).

The participants of the survey were 192 first-year students of RTTEMA, pre-service teachers, enrolled both in the full-time and part-time studies in various specialisation groups - the future primary school teachers, the teachers of dance and rhythmics, music teachers, education managers and the representatives of other specialisations. There were 185 women and 7 men among the respondents.

The analytical data processing software SPSS has been used for the analysis of the data. The reliability of the analysis and its internal consistency is characterised by Cronbach's alpha 0.78 .

\section{Results}

On average, approximately $90 \%$ of the surveyed students rate the introduction of innovations in the process of studies positively. It is equally important that the students recognise the need to develop students' and educators' interest and positive attitude with regard to the introduction of innovations in the process of education and to improve the work of organisations responsible for the coordination of activities concerning the introduction of innovations and development. The respondents appreciate the role of the management of the institutions of higher education in enhancing the motivation of students and the academic staff to create and introduce innovations (see Table 1). Students express their readiness for innovations.

Table 1. Students' views on innovative activities at the institution of higher education

\begin{tabular}{|c|c|c|}
\hline No. & Items & Respondents (\%) \\
\hline 1 & $\begin{array}{l}\text { By rationally harmonising the introduction of innovations with the effective experience of the } \\
\text { previous activity }\end{array}$ & 97.5 \\
\hline 2 & $\begin{array}{l}\text { To create opportunities for talented students to present their creative work in conferences and } \\
\text { engage in research projects }\end{array}$ & 95.0 \\
\hline 3 & $\begin{array}{l}\text { The support of governmental institutions in the introduction of innovations at the institutions of } \\
\text { higher education }\end{array}$ & 89.9 \\
\hline 4 & $\begin{array}{l}\text { To develop students' and educators' interest and positive attitude to the introduction of innova- } \\
\text { tions in the process of education at the institution of higher education }\end{array}$ & 87.4 \\
\hline 5 & To try to involve students in conducting research work & 83.2 \\
\hline 6 & To help students undertake their own innovative activity & 80.7 \\
\hline 7 & $\begin{array}{l}\text { To preserve the results achieved previously using traditional methods and to introduce separate } \\
\text { innovations }\end{array}$ & 71.4 \\
\hline 8 & $\begin{array}{l}\text { To develop efficient management attitude to the introduction of innovations at the institution of } \\
\text { higher education }\end{array}$ & 54.6 \\
\hline
\end{tabular}

More than $80 \%$ of the respondents state that they need help to undertake their own innovative activity: 
they want to participate in research projects and to present their creative work in scientific conferences. There is a good correlation among the answers $(r=0.357)$, and the correlation is significant at the 0.05 level (two-tailed), which implies that the majority of the students see their innovative activity in the area of research work, and they are ready to engage in it.

Of the respondents, $97.5 \%$ believe that the introduction of innovations has to be rationally harmonised with the effective experience of previous activity; on the other hand, a smaller number of the respondents (75.5\%) agree that high-priority issues have to be solved based on the previous experience at the institutions of higher education. Of the surveyed students, $96.4 \%$ of the consider that the support of governmental institutions is necessary for the introduction of innovations in higher education.

By means of the Pearson Chi-Square test, it was determined that there are no statistically significant differences between the views of full-time and part-time students. However, insignificant differences among the students of different specialisations with regard to the evaluation of the kinds of innovative activity were singled out. A significant difference between the views of the students whose specialisation is the primary school teacher and those specialising in education management can observed with regard to the question about the role of the management of the institutions of higher education - the future primary school teachers rate the efficient attitude of the institution's management to the introduction of innovations in higher education considerably higher than the future education managers $(p<0.001 ; \mathrm{a}=0.95)$; in fact, $73 \%$ of the respondents from the education management group gave a negative answer to this question. This result seems to be surprising and needs to be studied more thoroughly in the further research on this issue.

Students see the role of new technologies in the process of studies and link the introduction of innovations to these technologies. And $96 \%$ of the respondents have pointed out that it is important both for students and educators to receive information about new technologies and to find a possibility to acquire them.

Overall, it can be concluded that students' opinions are similar, and significant differences don't exist in their views. The surveyed students are open to innovations in the institutions of higher education.

Having analysed students' views on the personal qualities of the academic staff by means of the Pearson's Chi-Square test in order to determine which of these qualities facilitate cooperation in the process of studies most of all, the authors found that there are no statistically significant differences among the students of different specialisations. In the survey, $84 \%$ of the respondents appreciate educators' professionalism, intelligence $(72 \%)$, the ability to express their thoughts clearly and persuasiveness $(73 \%)$. Educators' respectful attitude towards students has also been given a high ranking by $71 \%$ of the respondents. Most of the respondents (67\%) evaluate positively the teachers' interest in their subject and erudition. Most of the students surveyed do not agree that their teachers are indifferent, haughty or self-seeking $(11 \%, 3 \%$ and $14.7 \%$ respectively). On the other hand, only $20 \%$ of the students have marked teachers' selflessness and belief in high ideals. After ranking educators' personal qualities according to the number of the respondents who have evaluated the particular quality positively, it can be seen that professionalism gets the highest ranking (see Figure 1).

Overall, students think that the cooperation between students and teachers in the introduction of innovations is important: $44 \%$ of the respondents rate it as very important, but $52 \%$ only as important. On average, $92 \%$ of the respondents believe that at present the academic staff can be spiritual advisers for students, while $32 \%$ fully regard them as their own role models, and 35\% partly believe so.

With regard to the evaluation of the relationships 'student-student' and 'teacher-student', the dominant qualities are friendliness and mutual trust. Only a very small number of the respondents see conflicting relationships in the academic environment ( $5 \%$ and $4 \%$ respectively). Hostile relationship can also be regarded as an insignificant phenomenon since none of the respondents had noticed it among students, and only $1 \%$ of the respondents characterise the relations between students and teachers in that way (see Table 2). 


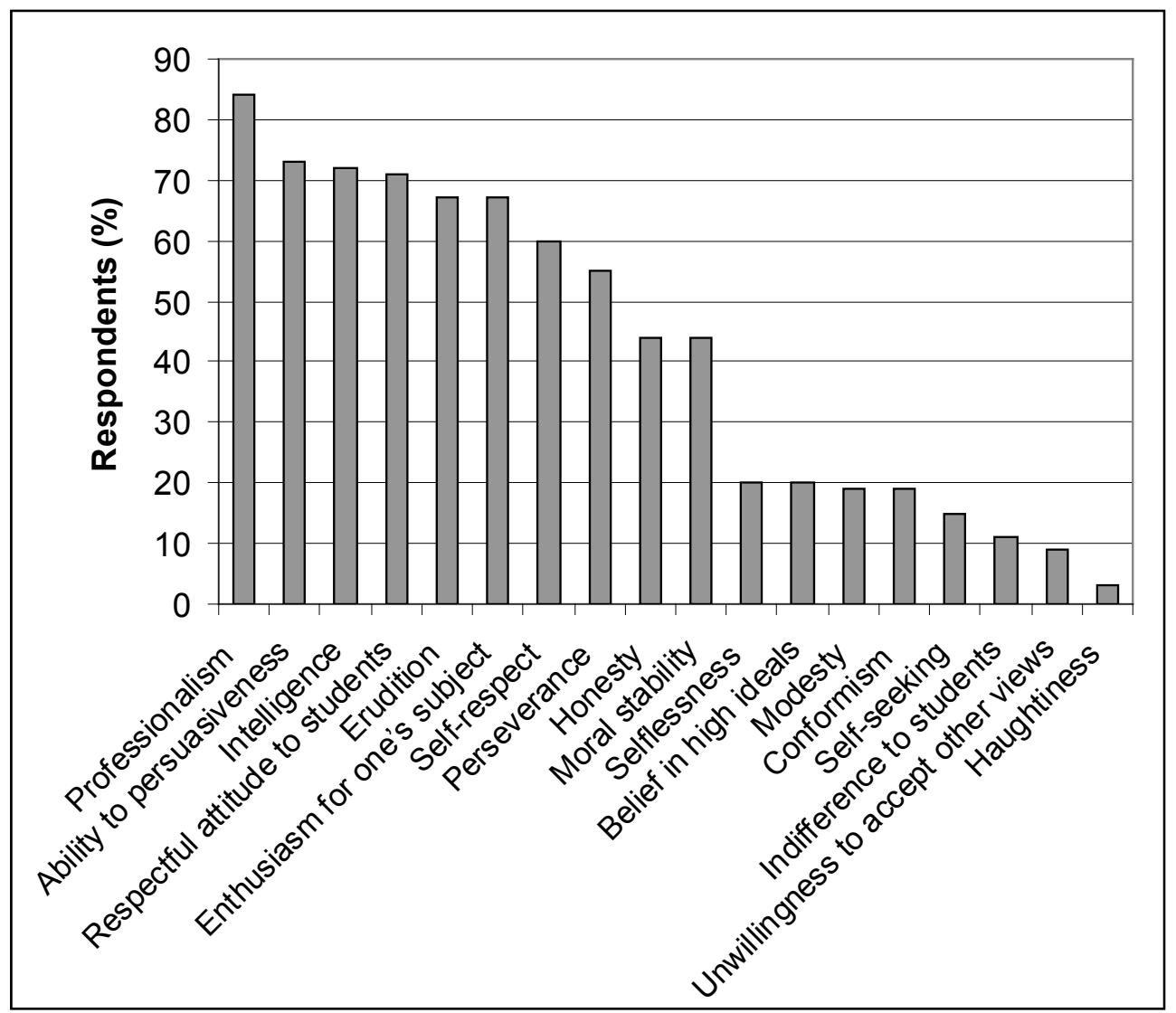

Figure 1. The most characteristic personal qualities of educators

Table 2. The characteristics of the mutual relationships 'student - student' and 'teacher - student'

\begin{tabular}{llll}
\hline \multirow{2}{*}{ No } & The nature of the relationship & \multicolumn{2}{l}{ Affirmative responses, the number of the respondents (\%) } \\
\cline { 2 - 4 } & & Relationship 'student - student' & Relationship 'teacher - student' \\
\hline 1 & Friendly & 89 & 60 \\
2 & Trusting & 37 & 52 \\
3 & Indifferent & 17 & 20 \\
4 & Hostile & 0 & 1 \\
5 & Tense & 13 & 8 \\
6 & Conflicting & 5 & 4 \\
\hline
\end{tabular}

As to the nature of teacher-student relationships, the data of the study show that the dominant relations can be characterised as the dialogue of subjects. The traditional strictly delimited social functions of the academic staff and students in the pedagogical process, namely, the teacher as the subject of education and the student as the object of education, have changed.

The idea of cooperation is very important in pedagogy; learning is not only a rational process, but also includes the evaluation of information and innovations (Tillla, 2005), which means that at the institutions of higher education, the cooperation between the academic staff and students have become a reality in the process of studies. This can be regarded as an innovative feature characterising the collaboration between the academic staff and students. The collaboration implies the shift in the position of both the teacher and students and the recognition of the equal rights of the participants in the process of learning - the teacher and students. 


\section{Conclusions}

The notion of "innovation" has a complex and multifaceted meaning in teacher education, which involves the process of renewal, educational reforms, the selection of the most appropriate material (idea, activity, form, method, means, concept or programme) and its implementation in practice, i.e. the creation, acquisition and application of innovations in the pedagogical practice.

Having analysed the data of the survey involving the first-year students, pre-service teachers, enrolled both in the full-time and part-time studies at RTTEMA (192 students), the authors of the article reached the conclusion that the innovative activity of the academic staff manifests itself in the implementation of equal collaboration as the pedagogical means in the process of studies, as well as the positive attitude of students and the academic staff to the necessity of introducing innovations.

The introduction of innovations in the pedagogical process is specific and is affected by teacher's personality. With regard to the teacher as their collaboration partner, the students rate the following qualities most positively: professionalism (84\%), intelligence ( $72 \%)$, the ability to express one's ideas clearly, persuasiveness (73\%), respectful attitude to students (67\%) and friendliness (89\%). On average, $92 \%$ of the students surveyed believe that the academic staff can be their advisors in solving problems.

The research proves that the innovative process of studies is the one where there is collaboration between the academic staff and students, and both the academic staff and students are equal collaboration partners.

The students' ideas concerning innovations in the process of studies are mainly related to students' individual participation, the use of new information technologies and the implementation of students' creative work.

\section{References}

Baltušite, R. (2012). The pedagogy students' readiness for professional activities in the school environment. Synopsis of the doctoral thesis. Jelgava: LLU. Retrieved 03.06.2015 from: http://llufb.llu.lv/dissertation-summary/pedagogics/Regiina_ Baltusiite_promoc_darba_kopsavilkums_2013_LLU_TF_IMI.pdf

Brigmane, B. (2014). Pieaugušo pašpieredzes veidošanās mācīšanās procesā Promocijas darbs [The formation of adults' self-experience in the process of learning. Doctoral thesis]. Rīga: RPIVA. Retrieved 20.05. 2015 from: http://www.rpiva.lv/ pdf/prom/bb_darbs.pdf (in Latvian)

Fried, I. (2006). Higher education governance in Europe: Autonomy, ownership and accountability: A review of the literature. In: Kohler, J. \& Huber, I. (Eds.) Higher education governance between democratic culture, academic aspirations and market forces. Brussels: Council of Europe Publishing, Series, No. 5.

Gedžūne, I. (2014). Orientation of pre-service teachers' frames of reference towards inclusion in nature. Synopsis of the doctoral thesis. Daugavpils: Daugavpils University. Retrieved 03.06. 2015from: http://du.lv/files/000/009/575/inga_ gedzune_promocijas_darbs_saved.pdf?1399888263

Grabovska, R. (2006). Ilgtspējības principa īstenošana skolotāju izglītībā Promocijas darbs [The implementation of the principle of sustainability in teacher education. Doctoral thesis]. Daugavpils: Daugavpils universitāte. Retrieved 12.06.2015from: www3.acadlib.Iv/greydoc/Grabovskas_disertacija/Grabovska_lat.doc (in Latvian)

Grabovska, R., \& Grabovskis, J. (2009). Implementing the United Nations Decade on Education for Sustainable Development in Latvian higher education. Journal of Teacher Education for Sustainability, 11(1), 18-30.

Kapenieks, J. (2013). Izglïtības darbības pētijums e-studiju vidē Promocijas darbs [Educational action research design for e-learning environments. Doctoral thesis]. Rīga: RTU. Retrieved 13.06.2015 from: http://www.liepu.lv/uploads/files/ Kapenieks)_Promocijas\%20darbs.pdf (in Latvian)

Kapenieks, J., \& Salīte, I. (2012). Action research for creating knowledge in an e-environment. Journal of Teacher Education for Sustainability, 14(2), 111-129.

Kunda, I. (2014). Inovācijas universitātē: varas un legitimitātes aspekti. Promocijas darbs [Innovations at university: Aspects of power and legitimacy. Doctoral dissertation]. Rīga: LU. Retrieved 15.05.2015from: http://www.szf.lu.lv/fileadmin/ user_upload/szf_faili/Bauhausi/Kunda_llona_2014.pdf (in Latvian)

Lukjanska, R. (2014). The analysis of the innovation capacity in Latvia in the context of the European region. Synopsis of the doctoral thesis. Jelgava: LLU. Retrieved 24.04.2015from: http://llufb.llu.lv/dissertation-summary/economics/Renate_ Lukjanska_promoc_darba_kopsav_2014_LLU_ESAF.pdf

Prensky, M. (2001). Digital game-based learning. New York: McGraw-Hill. 
Salīte, I., Gedžūne, G., \& Gedžūne, I. (2009). Educational action research for sustainability: Seeking wisdom of insight in teacher education. Journal of Teacher Education for Sustainability, 11(2), 14-30.

Tiḷla, I. (2005). Sociālkultūras mācišanās organizācijas sistēma [The organisational system for the studies of social culture]. Rīga: RaKa. (in Latvian)

Tisenkops, T., Bela, B., \& Kunda, I. (2011). Augstskolas regiionos: zināšanu un prakses mijiedarbe [Institutions of higher education in the regions: The interaction of knowledge and practice]. Rīga: Zinātne. (in Latvian)

UNESCO (2005). Guidelines and recommendations for reorienting teacher education to address sustainability. Education for Sustainable Development in action. Technical Paper No. 2, October 2005.

Woods, P. (2002). Teaching and learning in the new millennium. In: Day, C. \& Sugrue, C. (Eds.) Developing teachers and teaching practice (pp. 73-91). London: Routledge \& Falmer.

Zinātnes, tehnoloǵijas attīstības un inovācijas pamatnostādnes 2014.-2020.gadam, Pamatnostādṇu projekts [The guidelines for science, the development of technologies and innovations for the period of $2014-2020$. Draft.]. (2013). Rīga. Retrieved 18.03.2015 from: http://www.mk.gov.lv/lv/mk/tap/?pid=403062678mode=mk\&date=2013-12-17, (in Latvian)

Бережная, Т. Н. (2011). Формирование инновачионной методической культури учителя начальных классов в прочесе профессиональной подготовки в вузе [The formation of the innovative culture for primary school teachers in the process of professional teacher training at the institution of higher education]. Дисс. канд. пед. Наук [Unpublished Doctoral thesis]. Ставрополь, 211 стр. (in Russian)

Беспалько, В. П. (1995). Реформируются ли образование? [Is education undergoing reforms?] In: Беспалько, В.П. Мир образования [The world of education]. М. : Педагогика. (in Russian)

Беспалько, В. П. (2000). Психологические парадоксы образования [The psychological paradoxes of education] , M., Педагогика, , с. 13-20. (in Russian)

Бондаревская, Е. В. (2008). Педагогическая культура учителя в системе личностно -ориентированного образования [Teacher's pedagogical culture in the system of personality-oriented education]. In: Восnитание как встреча $\mathrm{C}$ личностью. Избранные педагогические труды в двух томах [Education as a meeting with the personality. Selected Works in Pedagogy in Two Volumes]. Ростов на Дону: РГПУ, с. 351-355. (in Russian)

Кларин, М. В. (1995). Инновачии в мировой педагогике [Innovations in the world pedagogy]. Рига: Педагогический центр” Эксперимент”, 176 стр. (in Russian)

Поляков, С. Д. (1993). В поисках педагогической инноватики [Searching for pedagogical innovations]. М.: Педагогика 138 стр. (in Russian)

Пригожин, А.И. (1989). Нововведения-стимулы и препятствия [Innovations - stimuli and obstacles], М.: Педагогика 56 стр. (in Russian)

Юсуфбекова, Н. Р. (1990). К проблеме разработки основ педагогической инноватики [On the issue of developing the foundations for pedagogical innovations] In: Новые исследования в педагогических науках [New research in pedagogy]. Вып.1(55), М.: Педагогика, с. 3-7. (in Russian) 